УДК: [378.147+355.233]:004.358

Людмила Анатоліївна Заӥка (кандидат педагогічних наук)

Олександр Васильович Лаврінчук (кандидат технічних наук, с.н.с.)

Валерій Олександрович Крайнов (кандидат технічних наук, доцент)

Національний університет оборони України імені Івана Черняховського, Київ, Україна

\title{
ВИКОРИСТАННЯ МОЖЛИВОСТЕЙ ЗАСОБІВ ІМІТАЦІЙНОГО МОДЕЛЮВАННЯ БОЙОВИХ ДІЙ У ХОДІ ПРАКТИЧНОЇ ПІДГОТОВКИ ОРГАНІВ ВІЙСЬКОВОГО УПРАВЛІННЯ
}

\begin{abstract}
Сучасні тендениії розвитку інформаційно-комунікаційних технологій, зокрема в середовищі засобів імітаційного моделювання військового призначення, світовий досвід їх використання в оперативній $i$ бойовій підготовиі військ створюють сприятливі умови для розвитку різних аспектів їх використання. У статті авторами розглянуто класифікацію таких засобів, обірунтовано використання можливостей засобів імітаційного моделювання бойових дій щзодо розвитку інтелектуальних, емоційно-вольових якостей військовослужбовців в умовах навчально-бойової обстановки для підвищення рівня їх навченості.

Грунтуючись на результатах проведених досліджень, досвіді використання сучасного засобу імітаційного моделювання бойових дій JCATS (Joint Conflict and Tactical Simulation) у 3 С України протягом останніх років, авторами досліджено иляхи використання результатів моделювання для оцінювання практичної складової навченості органів військового управління вже на одному із етапів підготовки органів управління бригад під час командно-чтабних навчань базового етапу бойової підготовки Сухопутних військ ЗС Украӥни. Керуючись зазначеними методиками проведення оцінювання та отриманими у ході імітаційного моделювання на ЈСАТS результатами (кількісними, результатами спостереження посередників, експертів тощз) автори розглядають можливість отримання кількісної оцінки рівня навченості органу військового управління.
\end{abstract}

Ключові слова: засіб імітаційного моделювання бойових дій, імітаційне моделювання, орган військового управління, навченість, JСАTS.

\section{Вступ}

Постановка проблеми. На підгрунті основних вимог Стратегії національної безпеки України, Воєнної доктрини України, Концепції розвитку сектору безпеки й оборони України актуальною проблемою сьогодення $\epsilon$ розвиток здатності Збройних сил (3С) України виконувати завдання за призначенням, зокрема шляхом удосконалення засад підготовки та застосування військ (сил) на основі принципів і стандартів НАТО, бойової та спеціальної підготовки військовослужбовців. Підготовленість особового складу поряд із станом укомплектованості частин i з'єднань, забезпеченістю ї матеріальними засобами та рядом інших умов є фактором, що визначає їх боєздатність.

Реформування і розвиток ЗС України стимулює, у свою чергу, вдосконалення системи підготовки офіцерських кадрів щодо досягнення іiі якості згідно зі стандартами НАТО, у тому числі із застосуванням інформаційно-комунікаційних технологій (ІКТ). Сучасні світові тенденції їх розвитку, зокрема в середовищі засобів імітаційного моделювання військового призначення, досвід використання в оперативній і бойовій підготовці військ (сил), розвитку інтелектуальних, емоційно-вольових якостей, психічної стійкості військовослужбовців в умовах навчально-бойової обстановки створюють сприятливі умови для формування та розвитку їх навченості.

Під час Базового періоду бойової підготовки Сухопутних військ ЗСУ відбувається централізована підготовка органів управління штабів бригад. Останні роки вона проводиться як у пунктах постійної дислокації, так і під керівництвом командувачів оперативних командувань в рамках запровадженої курсової підготовки в Національному університеті оборони України імені Івана Черняховського (НУОУ) [ ]. Одним із етапів підготовки органів управління бригад у НУОУ $\epsilon$ командно-штабні навчання (КШН) із застосуванням засобу імітаційного моделювання бойових дій (ЗІМБД) JCATS (Joint Conflict and Tactical Simulation).

Аналіз останніх досліджень і публікацій. Дослідження можливостей 3 оцінювання рівня 
навченості органів військового управління, методичні підходи та методики іiі проведення насьогодні $є$ актуальними та досить складними (О. Георгадзе, С. Дуденко, О. Макаліш, А. Носик, I. Рубан, С. Смірнов, С. Ткачук, В. Харабара та ін). Головне управління доктрин та підготовки Генерального штабу Збройних сил України спільно 3 центром оперативних стандартів і методики підготовки Збройних сил України (жовтень 2020) у відповідності до Доктрини з організації оцінювання (сертифікації) у ЗСУ розробило «Методичні рекомендації з оцінювання (сертифікації) органів військового управління військових частин (підрозділів) Збройних сил України щодо набуття визначених спроможностей» (далі - Методичні рекомендації) [10]. Документ визначає теоретичні положення, норми і правила щодо організації оцінювання органів військового управління, військових частин (підрозділів) видів, окремих родів військ (сил) щодо набуття визначених оперативних (бойових, спеціальних) спроможностей.

Грунтуючись на результатах проведених досліджень, досвіді використання ЗІМБД JCATS у 3С України протягом останніх років, набуває актуальності питання дослідження можливості проведення оцінювання практичної складової навченості органів військового управління із використанням засобів імітаційного моделювання бойових дій вже на базовому етапі бойової підготовки.

Мета статті: обгрунтувати можливість використання процесу та результатів імітаційного моделювання бойових дій, шляхи оцінювання навченості органу військового управління під час командно-штабних тренувань із застосуванням JCATS.

\section{Виклад основного матеріалу дослідження}

Аналіз тенденцій підвищення рівня підготовленості органів військового управління (ОВУ) в країнах НАТО та результативності процесу управління військами [1-14] засвідчує їх залежить від здатності командиру та фахівців ОВУ використовувати сучасні засоби інформаційнокомунікаційних технологій, зокрема імітаційного моделювання, на всіх етапах своєї діяльності. Особливо вони є корисними на етапі підготовки ОВУ наметі подолання протиріччя, що сьогодні виникає у практичній діяльності органів військового управління ЗС України: з одного боку, постійне збільшення об'єму інформації під час відпрацювання рішень та планів застосування сил та засобів потребує суттєвого збільшення часу на прийняття рішення органом управління, з іншого існує вимога багаторазового підвищення оперативності управління, що обумовлена новими способами та швидкими темпами ведення бойових дій. Вплив такого протиріччя посилюється сучасною міццю зброї, що застосовується, та дає змогу в окремих бойових епізодах досягати результатів раніше довготривалих військових дій. У зв'язку 3 цим спостерігається тенденція посилення наслідків недоліків та помилок управління ОВУ.

Дослідження результатів використання засобів імітаційного моделювання у військовій сфері, на нашу думку, ускладнюється вживанням різної термінології у працях закордонних та вітчизняних науковців, а саме: тренажерні комплекси, засоби імітаційного моделювання, засоби імітаційнорольового моделювання, комп'ютерні симуляції, програмно-імітаційні комплекси, симулятори, імітаційні комп’ютерні засоби навчання та ін.

Відповідно до класифікації НАTO LVC (Live,Virtual and Constructive) засоби імітаційного моделювання поділяють на три основних види: реальні - суб'єкти використовують зразки тренувального озброєння та військової техніки в полігонних умовах обстановки; віртуальні суб'єкти використовують віртуальні зразки одиниць озброєння й військової техніки або їх компоненти; конструктивні - комп'ютерні імітаційні програми та системи, у яких суб'єктами відбувається управління віртуальними моделями особового складу, озброєння та військової техніки в умовах динамічної електронної обстановки (бойових дій, навколишнього середовища та ін.) [14]. Вибір засобу чи тренажеру (реального, віртуального або конструктивного) залежить від форми підготовки (індивідуальна, колективна), рівнів застосування (тактичний, оперативний, стратегічний), навчальних цілей тренування, можливостей навчально-матеріальної та технічної бази локацій підготовки тощо. Закордонний досвід свідчить про результативність комплексного застосування систем засобів імітаційного моделювання під час заходів бойової підготовки військ (сил), освітнього процесу тощо. Розвиток використання таких засобів у підготовці військових фахівців ЗС України пов'язаний із наявністю, доцільністю та результативністю їх запровадження під час індивідуальної та колективної підготовки.

Наше дослідження грунтується на використанні конструктивного тренажера колективної підготовки - ЗІМБД JCATS. Імітаційне моделювання будемо розглядати як найбільше ефективний та універсальний варіант комп'ютерного моделювання в області дослідження та управління складними системами, під час якого логікоматематична модель (моделі) досліджуваної системи являє собою алгоритм ï функціонування, програмно реалізований на комп'ютері. ЗІМБД JCATS за допомогою послідовних обчислювань та графічного відображення їх результатів дає змогу відтворювати (імітувати) процеси функціонування системи об'єктів за умови впливу на них різних випадкових факторів. Кількісні результати такого імітаційного моделювання, його аналізу дають 
змогу виявляти заздалегідь невідомі (або ті, які важко передбачити) чинники (як то: можливості наявних засобів з ураження у визначеній місцевості зі складним рельєфом, ступінь ушкодження особового складу та військової техніки після масованого удару тощо) та спрогнозувати майбутні. Таким чином, JCATS здатний візуалізувати, обрахувати результати моделювання тактичних дій 3 прив'язкою до місцевості та умов у визначений час процесу імітаційного моделювання дій підрозділів чи сторін збройного конфлікту (рис.1).

Імітаційне моделювання управління бойовими діями можна розглядати на трьох рівнях управління. Перший рівень забезпечує моделювання в інтересах прийняття рішення командувачем, наприклад, оперативного об’єднання та постановки бойових задач тактичним військовим формуванням. Другий - охоплює процеси прийняття рішення та постановку бойових задач в тактичній зоні управління. Третій рівень це рівень виконавців поставлених бойових задач, тобто безпосередньо військових тактичних формувань. На такому рівні моделюється «практична» реалізація на JCATS прийнятих на двох попередніх рівнях рішень та відбувається зворотній зв'язок - отримання результатів впливів зімітованого середовища. Зазначене дає змогу готувати особовий склад підрозділів та управлінь до відпрацювання рішень в умовах обмеженості часу та невизначеності обстановки, що швидко змінюється. Таким чином створюється адекватне квазіпрофесійне середовище діяльності управлінського складу, який навчається, що, в свою чергу, дає змогу скоротити час та витрати на проведення реальних військових тренувань.

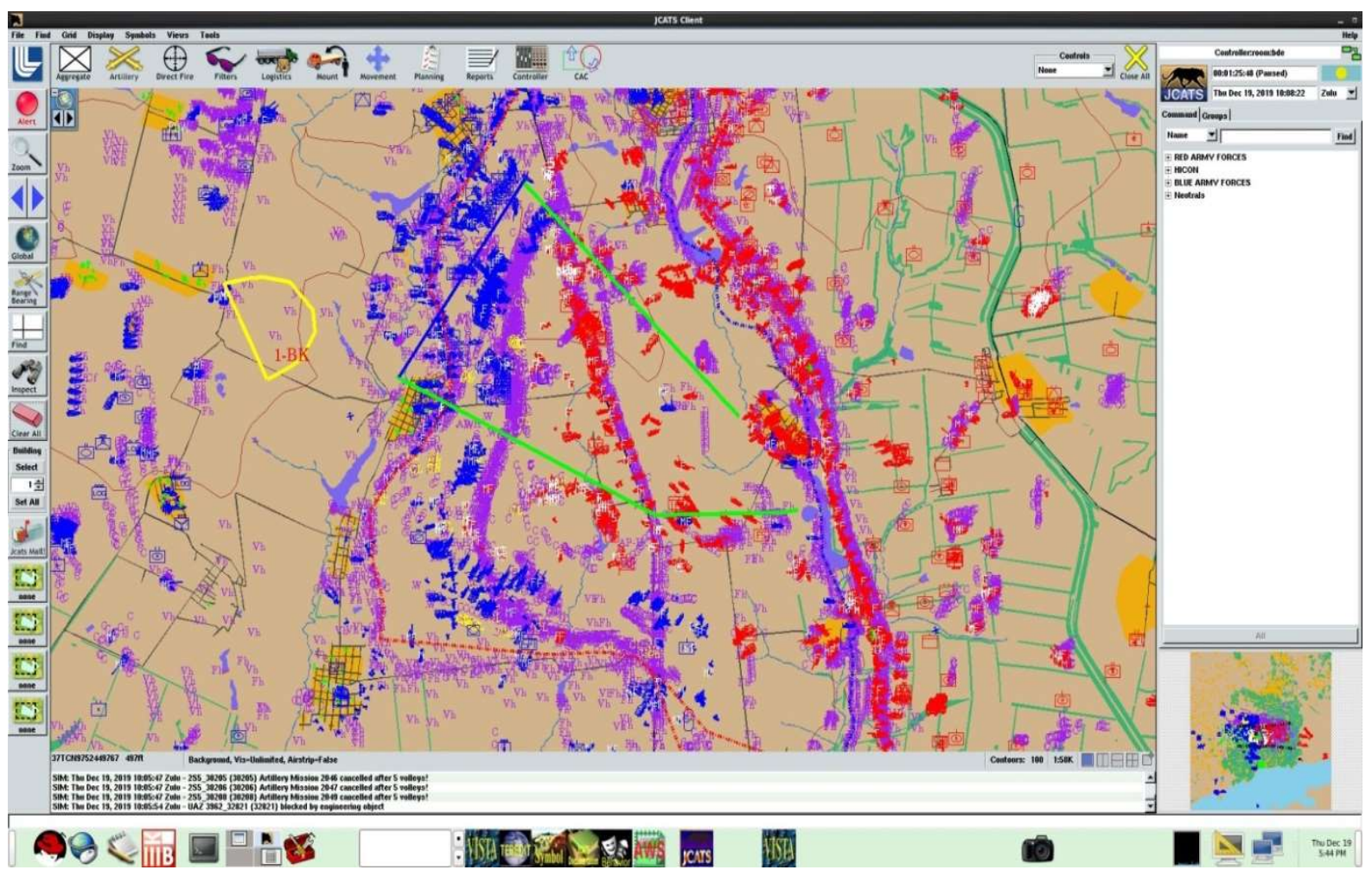

Рис. 1. Дисплей гри ЗІМБД JCATS із розіграшу наступу сил омпбр «Синіх» на укріплені позиції «Червоних»

Разом з тим, ЗІМБД JCATS не може підвищити швидкість виробки єдиного вірного та обгрунтованого рішення в умовах обстановки, що склалася, а є лише інструментом підтримання та активації мисленевої та творчої діяльності командувачів, командирів та посадових осіб штабів. Загальновідомо, що планування будь-якої операції чи бою є втіленням військового мистецтва командуючого чи тактичної підготовки командира поряд із їх здатністю особисто, на підставі власного досвіду та інтуїції прийняти відповідне до умов обстановки рішення. Імітаційна модель же в цьому випадку $є$ допоміжним інструментом підтримки даного процесу та оцінювання можливих альтернатив. Зазначене пов'язане 3 тим, що математичний апарат та алгоритми, що реалізуються в ньому, охоплюють складні процеси, фактори та умови, що безпосередньо впливають на результати моделювання. Частина 3 них задається кількісно, наприклад, бойовий та чисельний склад протиборчих угруповань військ; види та характеристики озброєння та військової техніки; ресурси, що виділяються; фізико-географічні та метеорологічні умови тощо. Другу частину вихідних даних за об'єктивними причинами неможливо представити у кількісному вимірі та врахувати під час моделювання, томущо вона «містить» когнітивну сферу людини та його 
морально-бойовий дух. Більше того, важливою перевагою використання імітаційного моделювання бойових дій під час тренувань різного рівня $\epsilon$ можливість впливу на його результат двобічного характеру протибірства, процесів протистояння двох антагоністичних систем (своїх сил та сил противника), що вступають між собою не тільки в бойове, але й в інтелектуальне протибірство, зумовлене задумами дій сторін конфлікту. Виходячи 3 цього, імітаційне моделювання бойових дій як і реальні бойові дії (операція чи бій) розглядаються не тільки як збройне протибірство двох таких сторін, але й як протибірство систем, що одночасно реалізують наявній свій інформаційний, бойовий, моральнопсихологічний та матеріально-технічний потенціал через реалізацію відповідних рішень підпорядкованими підрозділами. Відповідно, результат таких «бойових дій» необхідно розглядати крізь призму досягнення цілей та виконання поставлених бойових задач військами. Противник же розглядається як зовнішнє джерело непередбачуваних, а часом і невигідних дій, що примушує (ОВУ) управлінську ланку постійно шукати нові, відповідні до розвитку обстановки, рішення.

Відповідно до [9] за спільними координаційними процесами тренування із застосуванням ЗІМБД спостерігає керівний та посередницький апарат (експерти), що розробляють та супроводжують його.Вони оцінюють (відповідно до попередньо розробленого оціночного аркушу необхідних компетенцій, документів тощо) обсяг, якість та результат відпрацювання навчальної події кожною відповідальною особою органу управління. При чому, кожна із таких подій може мати свій індекс важливості (відносно до функціональних обов'язків) та відповідним чином впливати на кінцеві результати.

Таким чином, ЗІМБД JCATS дає змогу створити адекватне імітаційне середовище для функціонування відповідного органу управління на етапі практичних дій у ході ведення бойових дій. Зазначене, в свою чергу, дозволяє проводити оцінювання якості роботи органів військового управління у квазіпрофесійному середовищі, відтвореному із використанням ЗІМБД під час КШН.

У Методичних рекомендаціях оцінювання ОВУ наведено методику, яка складається 3 етапів оцінювання (планування оцінювання, проведення оцінювання, звітування). На третій фазі управління військами (підрозділами) у ході практичних дій (динамічна фаза) - етапу проведення оцінювання план контролю відпрацювання ввідних (MEL/MIL) адміністрації оцінювання розробляється на основі Плану нарощування обстановки (позначення дій противника) апарату керівництва навчання та відображає алгоритм оцінювання дій учасників у ході реагування на відповідні ввідні. В ході цієї фази групами (підгрупами) оцінювачів перевіряється навченість та здатність органу військового управління здійснювати уточнення планування та управляти підпорядкованими підрозділами (військами) у відповідності до вимог оціночних листів відповідних стандартів підготовки. Щоб визначити, чи вдалося об'єкту оцінювання під час виконання певного елемента досягнути показників (виконати норматив, вправу, прийом, прийняти рішення тощо), що відповідають позитивній оцінці, оцінювач (спостерігач) повинен фіксувати результати спостереження за ходом та якістю виконання кожного елемента оціночного листа використовуючи встановлені критерії (процедури) оцінювання відповідно до вимог нормативних документів видів, окремих родів військ (сил) ЗС України.

Оцінювання навченості проводиться під час перевірки злагодженості у ході проведення КШН за стандартами (завданнями) підготовки згідно 3 Інструкцією про порядок розроблення (розміщення) стандартів (каталогів завдань) 3 підготовки та проведення оцінювання за стандартами підготовки без використання Матриці критеріїв об'єктивного оцінювання [10, с. 40]. Оцінка за показником «навченість» здійснюється за критеріями «СПРОМОЖНИЙ», «ЧАСТКОВО СПРОМОЖНИЙ», «НЕСПРОМОЖНИЙ». Так за стандартом, наприклад, СТК 0101.411.0109 «Підготовка та ведення оборони в умовах відсутності або безпосереднього зіткнення 3 противником» може мати наступні розділи, які розподілені на елементи: 1. Підготовка оборонного бою. Прийняття рішення, віддання бойового наказу. 2. Підготовка штатних та доданих підрозділів до виконання завдань. 3. Підготовка доведення бойових дій. 4. Організація охорони та оборони. 5. Ведення оборонних дій. 6. Знищення противника, який вклинився. 7. Відновлення системи вогню, зруйнованих фортифікаційних споруд.

План контролю відпрацювання ввідних (Додаток 6 Методичних рекомендацій) складається 3 переліку основних ввідних (подій, інцидентів) оцінювання мб (омбр) із зазначенням часу події, задіяного підрозділу, місця, номеру стандарту підготовки, розпорядчого документу, назви інциденту, очікуваних дій, рольових гравців та ін. Замисел тренування має забезпечувати можливість оцінити всі визначені для об'єкту оцінювання питання, виявити всі заявлені (визначені) спроможності, що підлягають оцінюванню.

Таким чином, більшість висновків про результативність дій навчальної аудиторії, отримується на основі аналізу результатів методом аналізу шляхом спостереження, порівняння можливо із використанням кількісних даних результатів моделювання бойових дій під час обігу 
моделювання. Таки дані, наприклад, можуть включати у себе кількість втрат, кількість боєприпасів, що використовуються, бойовий потенціал підрозділів тощо (рис. 2). Сформовані таким чином оцінювальні аркуші будуть відбивати кількісну характеристику виконання запланованих дій (подій).

Автори статті «Методичний підхід до оцінювання рівня навченості органів військового управління тактичного рівня» Макаліш О.В., Георгадзе О.А, складову запропонованої та викладеної у статті оцінки рівня навченості органу військового управління тактичного рівня (сукупний рівень індивідуальних спроможностей) визначають показниками $B_{y j}(t), \quad$ які характеризують рівень розвитку окремого військовослужбовця ОВУ на час $\mathrm{t}$ : «теоретичних знань» $B_{m y j}(t)$, «практичних умінь» $B_{n y j}(t)$, «психологічних якостей» $B_{\text {пся }}(t)[6]$.

Показник $B_{m y j}(t)$ характеризує рівень теоретичних знань ј-го офіцеру органу військового управління, який пропонується розраховувати за відповідною формулою за результатами теоретичних опитувань (тестувань) 3 основних розділів проведеного курсу. Показник, що характеризує рівень психологічних якостей j-го військовослужбовця $B_{\text {пся }}(t), \quad$ пропонується розраховувати на основі таких психологічних якостей індивіда, як рівень нервово-психічної стійкості та спрямованості особистості. Розрахунок зазначених показників може бути проведений шляхом тестування військовослужбовців. Показник практичних умінь $B_{n y j}(t)$ грунтується на якості та результативності виконання офіцером органу військового управління своїх посадових обов'язків, які складно перевірити в умовах освітньої підготовки. Квазіпрофесійне середовище, яке створюється із застосуванням ЗІМБД під час КШН, дає змогу оцінити дії кожного посадовця органу військового управління на всіх етапах прийняття та реалізації рішення, отримати кількісну оцінку результату таких дій. Відтак, оцінювання практичних умінь та навичок військовослужбовців стає більше (більш) об'єктивним.

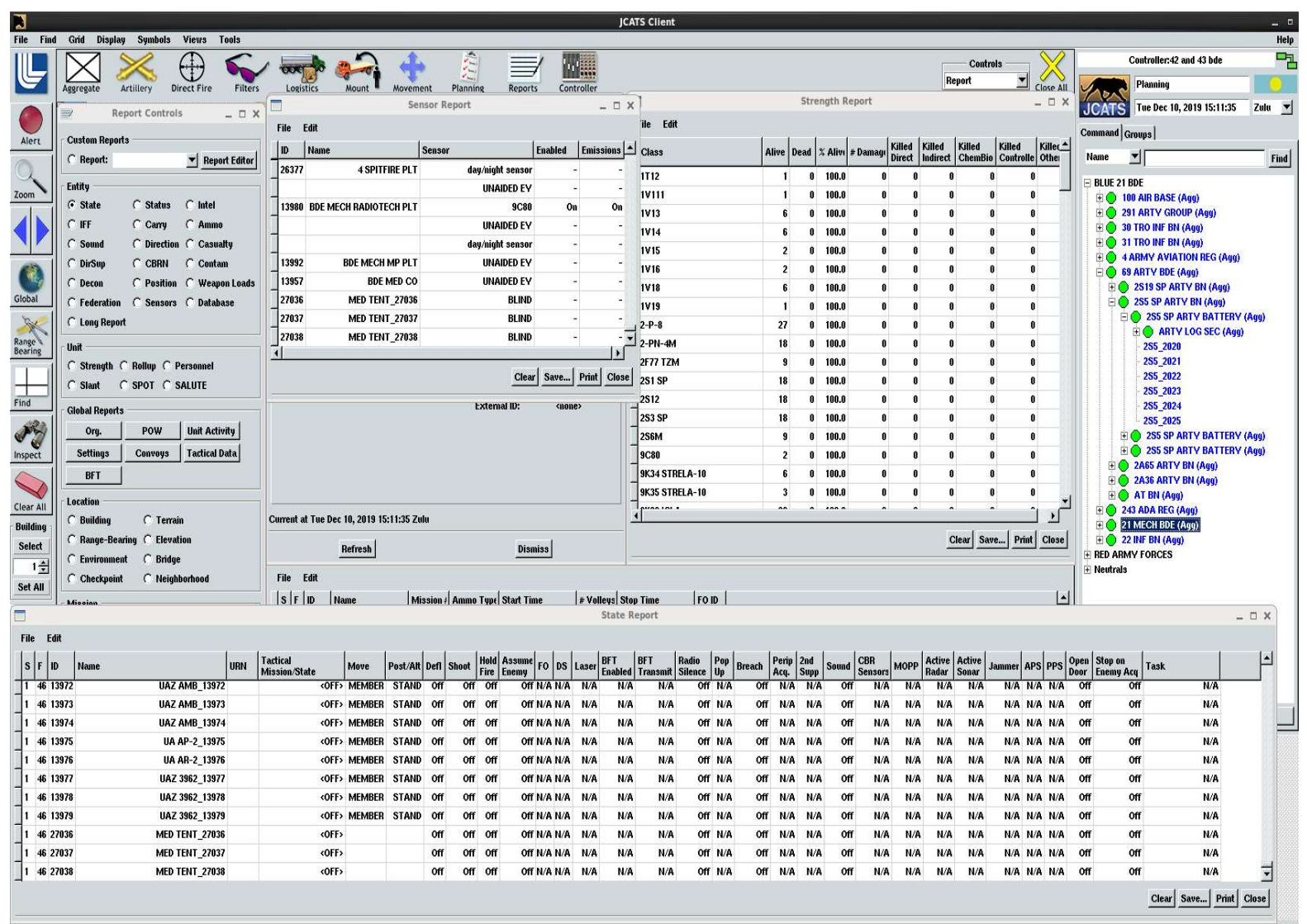

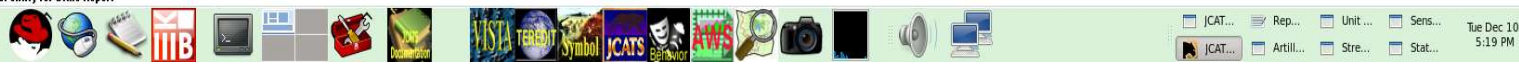

Рис. 2. Звітні меню засобу імітаційного моделювання бойових дій JCATS

Показник, який характеризує рівень практичних умінь ј-го військовослужбовця $B_{n y j}(t)$ розраховується за результатами виконаних ним практичних завдань. Зміст та кількість завдань має враховувати функціональне призначення військовослужбовця відповідно до займаної посади. Оцінювання рівня практичних умінь військовослужбовця $B_{n y j}(t)$ визначається за виразом: 


$$
B_{n y j}(t) \frac{X_{\text {викj }}(t)}{X_{\text {зав }}}
$$

де $X_{\text {викj }}(t)$ - кількість виконаних завдань ј-м військовослужбовцем;

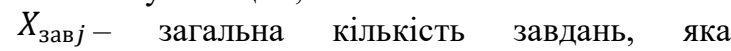
перевірялася у ј-го військовослужбовця.

Злагодженість органу військового управління авторами пропонується розраховувати за результатами практичної роботи органу військового управління у ході проведення тренувань за стандартами підготовки [6, с.106]. Так, наприклад, кожен стандарт підготовки складається 3 розділів стандарту, які характеризують спроможність органом військового управління виконувати певні завдання. Оцінювання стандарту у цілому може визначатися за оцінками розділу стандарту. В свою чергу, розділи стандарту підготовки складаються із завдань (процедур), які необхідно виконати органу військового управління, та оцінюються у визначений спосіб.

Таким чином, оцінювання сукупного рівня індивідуальних військовослужбовців органу військового управління тактичного рівня та їх злагодженості із використанням ЗІМБД JCATS під час проведення КШН дає змогу оцінювати рівень навченості такого органу.

Особливою перевагою тренувань із використанням ЗІМБД $є$ можливість та необхідність проведення спільного із всіма учасниками тренування детального аналізу проведених дій (АПД) [9;11]. Зібрані результати дій та оцінювання у кінці тренування аналізуються, демонструються збережені скріншоти епізодів розіграшу оперативно-тактичної обстановки, загальні відеоролики (реплеї). Зазначене забезпечуе прозорість та зрозумілість проведеного оцінювання. Усвідомлення офіцерами, що навчаються, результату власних успішних i неуспішних управлінських рішень також підвищують їх професійну мотивацію. Відтак, аналіз проведених дій також є засобом ефективного впливу на процес підготовки для досягнення максимальної результативності тренування.

Ще однією перевагою використання систем імітаційного моделювання, зокрема ЗІМБД ЈСАТS, $\epsilon$ можливість здійснення «серії прогонів» імітаційної моделі бойових дій, у ході яких може відбуватися оцінювання іiі функціонування при іншому наборі умов (навколишнього середовища, складу сил, видів озброєння тощо), наборі вхідних даних (підтримки сил старшого начальника, даних розвідки тощо) та керованості параметрів (стандартів процесу управління тощо). Метою проведення серії імітаційних досліджень $\epsilon$ отримання нових характеристик моделі бойових дій військ при зміні параметрів, структурних взаємозв'язків імітаційної програми. Зазначене дає змогу підвищувати рівень навченості та розвиток професійних навичок (особового складу ОВУ) управління через виконання порівняльного аналізу успішності рішень ОВУ.

Отже, у ході проведеного обгрунтування можливості використання процесу імітаційного моделювання та отриманих для оцінювання навченості органу військового управління результатів із використанням ЗІМБД ЈСАTS можна зробити висновок, що розглянуті елементи методик [6;10] демонструють наявні шляхи проведення такого оцінювання, його доцільність та результативність. До того ж, ЗІМБД ЈCATS як відмінний інструмент аналізу, моделювання дає можливість виявлення наслідків прийнятих управлінських рішень, тактики або доктринальних положень у різних часових, територіальних середовищах шляхом розіграшу відповідних сценаріїв, а, за необхідності, й повторення їх.

Підкреслюючи актуальність проведеного дослідження, зазначимо, що сучасна обмеженість обсягів забезпечення потреб ЗС України спонукає фахівців до використання сучасного засобу імітаційного моделювання бойових дій JCATS у $3 \mathrm{C}$ України для підвищення рівня підготовленості ланки військових управлінців усіх рівнів, оскільки (за інших рівних умов) помилки управління виявляються більш вирішальними для процесу функціонування будь-якої системи професійної діяльності, ніж помилки виконавчих підсистем.

\section{Висновки і перспективи подальших досліджень}

Отже, у ході проведеного обгрунтування можливості використання процесу імітаційного моделювання та отриманих для оцінювання навченості органу військового управління результатів із використанням ЗІМБД JCATS можна зробити висновок, що розглянуті елементи методик [6;10] демонструють наявні шляхи проведення такого оцінювання, його доцільність та результативність. До того ж, ЗІМБД ЈCATS як відмінний інструмент аналізу, моделювання дає можливість виявлення наслідків прийнятих управлінських рішень, тактики або доктринальних положень у різних часових, територіальних середовищах шляхом розіграшу відповідних сценаріїв, а, за необхідності, й повторення їх.

Підкреслюючи актуальність проведеного дослідження, зазначимо, що сучасна обмеженість обсягів забезпечення потреб ЗС України спонукає фахівців до використання сучасного засобу імітаційного моделювання бойових дій JCATS у 3 C України для підвищення рівня підготовленості ланки військових управлінців усіх рівнів, оскільки (за інших рівних умов) помилки управління виявляються більш вирішальними для процесу функціонування будь-якої системи професійної діяльності, ніж помилки виконавчих підсистем. 


\section{Лimepamypa}

1. Загорка О.М., Риспасв А.Н. Методичні положення оцінювання рівня підготовленості посадових осіб органів військового управління. Збірник наукових прачь Начіонального університету оборони України “Труди університету”. 2013. № 1 (115). С. 26-32. 2. Калачова В.В., Дуденко С.В., Бойко В.В, Бабенко О.П. Аналіз основних тенденцій та напрямків розвитку тренажерної бази в контексті підвищення якості підготовки особового складу Повітряних Сил Збройних Сил України. Системи озброєння і військова техніка. 2011. С. 206-210. 3. Концепція підготовки Збройних Сил України. Наказ Міністерства оборони Украӥни та Генерального штабу Збройних Сил України від 22.02.2016 № 95. К.: МОУ та ГШ ЗСУ, 2016. 14 с. (Нормативний документ Міністерства оборони України та Генерального штабу Збройних Сил України. Наказ). 4. Костина О.М., Корецький А.А. Щодо оцінки рівня готовності штабу (органу управління) з'єднання (частини) до виконання завдань за призначенням. Збірник наукових пращь Начіональної академії оборони Украӥни "Труди академї”. 2005. №60. С. 62-68. 5. Майстренко О. В., Бубенщиков Р. В., Стеців С. В. Застосування засобів імітаційного моделювання у процесі підготовки майбутніх офіцерів збройних сил України до виконання службових обов'язків. Інформаційні технології $i$ засоби навчання, 2020, Том 75, №1. С.186-201. 6. Макаліш О.В., Георгадзе О.А. Методичний підхід до оцінювання рівня навченості органів військового управління тактичного рівня. Збірник наукових праць Центру воєнностратегічних досліджень Національного університету оборони України імені Івана Черняховського. 2016. № 3(58). С.104-108. 7. Матвієвський О.М. Обгрунтування характеристик тренажерних засобів і систем. Наука $i$ оборона. 2010. С. 58-62. 8. Матвісвський О.М. Спроможність тренажерних засобів забезпечити бойову підготовку Сухопутних військ. Матеріали доповідей засідання круглого столу Центру дослідження армії, конверсї та роззброєння. 2012. С .47-49. 9. Методика підготовки і проведення командно-штабних навчань за допомогою комп'ютерів 3 використанням технологій імітаційного моделювання : метод. посіб. / В. С. Бобильов та ін. Київ: НУОУ, 2011. 85 с. 10. Методичні рекомендації з оцінювання (сертифікації) органів військового управління, військових частин (підрозділів) Збройних сил України щодо набуття виснажених спроможностей. Головне управління доктрин та підготовки Генерального штабу Збройних Сил Украӥни спільно з центром оперативних стандартів і методики підготовки Збройних Сил України. К.: МОУ та ГШ ЗСУ, 2020. 79 с. 11. Методика підготовки та проведення навчальних занять 3 оперативно-тактичних дисциплін 3 використанням засобів імітаційного моделювання бойових дій : метод. посіб. / В. Є. Бобильов та ін. ; за заг. ред. С. М. Салкуцана. Київ : НУОУ, 2015. 40 с. 12. Рубан І.В., Смірнов С.Б., Дуденко С.В., Носик А.М., Ткачук С.С. Підхід до оцінювання бойової виучки органів управління Збройних сил України. Системи обробки інформації, 2012, випуск 5 (103) с.165-172. 13. Рудковський О.М. Інтегрування системи тренажерів у процес бойової підготовки підрозділів Сухопутних військ. Академія сухопутних військ імені гетьмана Петра Сагайдачного, Львів. 2013. С. 99-104. 14. Loper L., C. Turnitsa, History of combat modelling and distributed simulation, in: A. Tolk (Ed.). Engineering Principles of Combat Modeling and Distributed Simulation. Wiley, 2012, № 16, P. 331-355

\title{
ВИКОРИСТАННЯ МОЖЛИВОСТЕЙ ЗАСОБІВ ІМІТАЦІЙНОГО МОДЕЛЮВАННЯ БОЙОВИХ ДІЙ У ХОДІ ПРАКТИЧНОЇ ПІДГОТОВКИ ОРГАНІВ ВІЙСЬКОВОГО УПРАВЛІННЯ
}

\author{
Людмила Анатольевна Заика (кандидат педагогических наук) \\ Александр Васильевич Лавринчук (кандидат технических наук, с.н.с.) \\ Валерий Александрович Крайнов (кандидат технических наук, доцент)
}

\section{Национальный университет обороны Украины имени Ивана Черняховского, Киев, Украина}

Современные тенденџии развития информационно-коммуникационных технологий, в частности, в среде средств имитационного моделирования военного назначения, мировой опьт их использования в оперативной и боевой подготовке войск создают благоприятные условия для развития различных аспектов их использования. В статье авторами рассмотрена классификация таких средств, обосновано использование возможностей средств имитационного моделирования боевых действий в развитии интеллектуальных, эмоционально-волевых качеств военнослужащих в условиях учебно-боевой обстановки для повышения уровня их обученности. Основываясь на результатах проведенных исследований, опыте использования современного средства имитационного моделирования боевых действий JCATS (Joint Conflict and Tactical Simulation) в ВС Украины на протяжении последних лет, авторами исследованы пути использования результатов моделирования для оценки практической составляющей обученности органов военного управления уже на одном из этапов подготовки органов управление бригад во время командно-итабных учений базового этапа боевой подготовки Сухопутных войск ВС Украины. Руководствуясь указанными методиками проведения оиенки и полученными в ходе имитационного моделирования на JCATS результатами (количественньми, результатами наблюдения посредников, экспертов и т.n.), авторы рассматривают возможность получения количественной оценки уровня обученности органа военного управления.

Ключевые слова: средство имитационного моделирования боевых действий, имитационное моделирование, орган военного управления, обученность, JCATS 

MILITARY ADMINISTRATIVE BODIES

\author{
Liudmyla Zaika (candidate of pedagogical sciences) \\ Oleksandr Lavrinchuk (candidate of technical sciences, senior researcher) \\ Valerii Krainov (candidate of technical sciences, associate professor)
}

\title{
National Defence University of Ukraine named after Ivan Cherniakhovsky, Kyiv, Ukraine
}

Modern trends in the development of information and communication technologies; in particular, in the environment of military simulation tools, world experiences in the operational and combat training of troops create favorable conditions for the development of various aspects of their use. In the article, authors considered the classification of such means, substantiated using of simulation means capabilities in combat exercises to develop intellectual, emotional, and volitional qualities of servicemen in a combat training environment to increase the level of their training. Based on the results of the research, the experience of use the modern combat operations simulation tool JCATS (Joint Conflict and Tactical Simulation) in the Ukrainian Armed Forces over the past years, authors have investigated ways of use simulation results to assess practical component of military administrative bodies training at one of the stages of brigade staffs preparation during command exercises of the basic stage of combat training of the Ground Forces of the Armed Forces of Ukraine. Guided by the indicated assessment methods and results obtained in the course of simulation modeling on JCATS (quantitative, observation results of mediators, experts, etc.), authors consider the possibility of obtaining a quantitative assessment of level training of the military administrative body.

Keywords: combat operations simulation tool, simulation, military command, training, JCATS.

\section{References}

1. Zahorka O.M., Ryspaiev A.N. Metodychni polozhennia otsiniuvannia rivnia pidhotovlenosti posadovykh osib orhaniv viiskovoho upravlinnia. Zbirnyk naukovykh prats Natsionalnoho universytetu oborony Ukrainy "Trudy universytetu”. 2013. № 1 (115). S. 26-32. 2. Kalachova V.V., Dudenko S.V., Boiko V.V, Babenko O.P. Analiz osnovnykh tendentsii ta napriamkiv rozvytku trenazhernoi bazy $\mathrm{v}$ konteksti pidvyshchennia yakosti pidhotovky osobovoho skladu Povitrianykh Syl Zbroinykh Syl Ukrainy. Systemy ozbroiennia i viiskova tekhnika. 2011. S. 206-210. 3. Kontseptsiia pidhotovky Zbroinykh Syl Ukrainy. Nakaz Ministerstva oborony Ukrainy ta Heneralnoho shtabu Zbroinykh Syl Ukrainy vid 22.02.2016 № 95. K.: MOU ta HSh ZSU, 2016. 14 s. (Normatyvnyi dokument Ministerstva oborony Ukrainy ta Heneralnoho shtabu Zbroinykh Syl Ukrainy. Nakaz). 4. Kostyna O.M., Koretskyi A.A. Shchodo otsinky rivnia hotovnosti shtabu (orhanu upravlinnia) ziednannia (chastyny) do vykonannia zavdan za pryznachenniam. Zbirnyk naukovykh prats Natsionalnoi akademii oborony Ukrainy “Trudy akademii”. 2005. №60. S. 62-68. 5. Maistrenko O. V., Bubenshchykov R. V., Stetsiv S. V. Zastosuvannia zasobiv imitatsiinoho modeliuvannia $u$ protsesi pidhotovky maibutnikh ofitseriv zbroinykh syl Ukrainy do vykonannia sluzhbovykh oboviazkiv. Informatsiini tekhnolohii i zasoby navchannia, 2020, Tom 75, №1. S.186-201. 6. Makalish O.V., Heorhadze O.A. Metodychnyi pidkhid do otsiniuvannia rivnia navchenosti orhaniv viiskovoho upravlinnia taktychnoho rivnia. Zbirnyk naukovykh prats Tsentru voienno-stratehichnykh doslidzhen Natsionalnoho universytetu oborony Ukrainy imeni Ivana Cherniakhovskoho. 2016. № 3(58). S.104-108. 7. Matviievskyi O. Obgruntuvannia kharakterystyk trenazhernykh zasobiv i system. Nauka i oborona. 2010. S.
58-62. 8. Matviievskyi O.M. Spromozhnist trenazhernykh zasobiv zabezpechyty boiovu pidhotovku Sukhoputnykh viisk. Materialy dopovidei zasidannia kruhloho stolu Tsentru doslidzhennia armii, konversii ta rozzbroiennia. 2012. S .4749. 9. Metodyka pidhotovky i provedennia komandnoshtabnykh navchan za dopomohoiu kompiuteriv $\mathrm{z}$ vykorystanniam tekhnolohii imitatsiinoho modeliuvannia : metod. posib. / V. Ye. Bobylov ta in. Kyiv : NUOU, 2011. 85 s. 10. Metodychni rekomendatsii z otsiniuvannia (sertyfikatsii) orhaniv viiskovoho upravlinnia, viiskovykh chastyn (pidrozdiliv) Zbroinykh syl Ukrainy shchodo nabuttia vysnazhenykh spromozhnostei. Holovne upravlinnia doktryn ta pidhotovky Heneralnoho shtabu Zbroinykh Syl Ukrainy spilno $\mathrm{z}$ tsentrom operatyvnykh standartiv i metodyky pidhotovky Zbroinykh Syl Ukrainy. K.: MOU ta HSh ZSU, 2020. 79 s. 11. Metodyka pidhotovky ta provedennia navchalnykh zaniat $\mathrm{z}$ operatyvno-taktychnykh dystsyplin $\mathrm{z}$ vykorystanniam zasobiv imitatsiinoho modeliuvannia boiovykh dii : metod. posib. / V. Ye. Bobylov ta in. ; za zah. red. S. M. Salkutsana. Kyiv : NUOU, 2015. 40 s. 12. Ruban I.V., Smirnov Ye.B., Dudenko S.V., Nosyk A.M., Tkachuk S.S. Pidkhid do otsiniuvannia boiovoi vyuchky orhaniv upravlinnia Zbroinykh syl Ukrainy. Systemy obrobky informatsii, 2012, vypusk 5 (103) s.165172. 13. Rudkovskyi O.M. Intehruvannia systemy trenazheriv $\mathrm{u}$ protses boiovoi pidhotovky pidrozdiliv Sukhoputnykh viisk. Akademiia sukhoputnykh viisk imeni hetmana Petra Sahaidachnoho, Lviv. 2013. S. 99-104. 14. Loper L. , C. Turnitsa, History of combat modelling and distributed simulation, in: A. Tolk (Ed.). Engineering Principles of Combat Modeling and Distributed Simulation. Wiley, 2012, № 16, R. 331-355. 